\title{
Hat Sanatının Sergilenme Usûlü ve Dijital Mecrada Hat Sanatı
}

Araştırma

Research

\section{Serkan Selalmaz}

Hattat, Yüksek Lisans Öğrencisi, Necmettin Erbakan Üniversitesi, Sosyal Bilimler Enstitüsü, Geleneksel Türk Sanatları Bölümü Anabilim Dalı

Calligrapher, MA Student, Necmettin Erbakan University, Institute of Social Sciences, Department of Traditional Turkish Arts, Konya, Turkey

serkan.selalmaz@gmail.com

https://orcid.org/0000-0003-2252-4545

Yazar

Author

Selalmaz, Serkan. "Hat Sanatının Sergilenme Usûlü ve Dijital Mecrada Hat Sanatı". Tevilat 2/1 (2021), 107-125.

doi https://doi.org/10.53352/tevilat.960707

Atıf

Cite as

Received / Geliș Tarihi: 2021-07-01

ISSN: 2687-4849 e-ISSN: 2757-654X

Accepted / Kabul Tarihi: 2021-10-11

www.tevilat.com

Bilgi

Bu makale, en az iki hakem tarafindan incelendi ve intihal içermediği teyit edildi.

Info

Cilt, tezhip ve ebrû gibi İslam sanatları, hat sanatının merkezî rolüyle gelişmiştir. Hat sanatının teşhiri başlangıçta Kur'an-ı Kerim'in istinsahı ve yapılar üzerindeki kitabelerle olmuştur. İslam medeniyeti, farklı milletlerle farklı coğrafyalarda temsil edilmiş ancak hepsinin ortak sanatı her zaman hat sanatı olmuştur. Orta Çağda net bir şekilde kaideleri ve kuralları olan tek sanatın hat sanatı olduğu bilinmektedir. Hat sanatı tarihin hiçbir döneminde belirli bir zümreye has kalmamıș, her zaman toplumun tüm kesimlerinin ilgisini çeken bir sanat olmuștur. Yüzyıllar boyunca değișen şehirler, gelișen teknolojilere rağmen hat sanatına olan ilgi hiçbir zaman eksilmemiş, bilakis her dönem artarak devam etmiştir. Yazıya çok hürmet gösteren Türkler, özellikle XV. asırdan sonra hat sanatında öncülüğü temsil etmiş, dünyaca ünlü sanatkârlar yetiştirmiş ve yeni yazı türleri icat etmiştir. Hat sanatının sergilendiği zeminler mimari eserler, kitaplar ve levhalardan müteşekkildir. Araştırmamız hat sanatının teşhirinin geçirdiği dönemleri, günümüzde dijital mecrada hat sanatının sergilenmesi hususundaki menfi ve müspet sonuçları değerlendirmeyi ve bu bağlamdaki bazı yeni sorularla literatüre katkıda bulunmayı hedeflemektedir.

Anahtar Kelimeler: Geleneksel Türk Sanatları, Hat Sanatı, Kitabe, Levha, Sanal Sergiler. 


\section{Exhibition Method of Islamic Calligraphy and Islamic Calligraphy in Digital Media}

Islamic arts such as bookbinding, illumination and marbling developed within the scope of Islamic calligraphy. The display of calligraphy was initially associated with the copying of the Qur'an and the inscriptions on the buildings. Islamic civilization has been represented by different nations and in different geographies, but the common art of this civilisation has always been Islamic calligraphy. It is known that the only art with clear rules in the Middle Ages was calligraphy. Islamic calligraphy has never created its aristocracy in any period of history, it has always been an art that all segments of society are interested in. Despite the changing cities and developing technologies over the centuries, the interest in the art of calligraphy has never decreased, on the contrary, it has continued to increase in each period. The Turks, who have shown great respect to Islamic calligraphy, pioneered in calligraphy especially after the 15th century, brought up world-famous artists and invented new writings. The exhibition mediums of calligraphy were comprised of architectural works, book arts and plates. This study, in which we investigate the negative and positive results of the exhibition of calligraphy particularly in the digital environment today, is not enough, but we want to give an idea and ask further questions for future researchers.

Abstract

Keywords: Traditional Turkish Arts, Islamic calligraphy, Epitaph, Painting, Virtual Exhibitions.

\section{Giriş}

Hat sanatı Kur'an-ı Kerim'in istinsah edilmeye başlandığı dönemden itibaren kitap sanatlarının; mimari eserlerin kitabelerinde yer almasıyla da İslam sanatlarının temelini olușturan bir yazı sanatıdır. Kitap sanatlarında tezhip, ebrû ve cilt sanatı; mimaride ise kalem işi, çini ve taş işçiliği hat sanatına bağlı olarak gelişmiştir. Hat sanatının sergilenmesi asırlar boyunca cami, medrese, han ve çeşme gibi anıtsal mimari eserler ve İslam medeniyetinde önemli yere sahip yazma eserlerden olan Delâil'ül-Hayrât, Kasîdetü'l-Bürde gibi meşhur eserlerin yanı sıra, mesneviler ve diğer edebi eserler vasıtasıyla olmuştur. Kâğıt yapma tekniklerinin gelişmesi levhaların asılmasına imkân sağlamış, insanların tekke, zaviye, ev ve işyerlerine besmele-i şerif, hilye-i saadet ve ayet-i kerime asma istekleriyle levha yazıları zaman içinde gelişmiştir.

Günümüzde teknolojik gelişmelerle sosyal hayatımız ve alışkanlıklarımız değiștiği gibi hat sanatının teşhir alanı da değişmiştir. Bugün kişisel web siteleri, blog sayfaları, Facebook, Instagram ve Twitter gibi sosyal medya mecraları sergi alanlarının başında gelmektedir. Bu araştırmamızda hat sanatının kısa tarihini, hat sanatının yüzyıllar içinde değişen teşhir usullerine günümüzün getirdiği yenilikleri ve bu yeniliklerin olumlu-olumsuz yönlerini değerlendirmeye gayret edeceğiz. 


\section{Hat Sanatının Tarihi}

Kur'an-ı Kerim Hz. Muhammed (S.A.V) aracılığıyla insanlara ulaştığında muhatap kavimdeki halk sözlü kültürün hâkim olduğu bir yapıya sahipti. Sözlü kültürün yaygın olması yazının olmadığı anlamına gelmemektedir. Hz. Peygamber'in doğumundan önceki yıllara tarihlenen Arapça kitabelerin, Nabatî yazıyla benzerliği sebebiyle Arap yazısının Nabatî yazısından meydana geldiği düşünülmektedir. ${ }^{1}$ Araplar, İslâmiyet'le birlikte yeni bir yaşam modelini benimsemiş ve hızla bu yaşam şekli farklı coğrafyalara ulaşmıştır. Hz. Peygamber'in Bizans, Pers ve Habeşistan'a gönderdiği İslâm'a davet mektupları İslâm medeniyetinin ilk yazılı metinleri olarak kabul edilebilir. Peyderpey inen ayetlerin vahiy katipleri tarafından yazıldığı bilinmektedir. Allah'ın sözlerini en güzel şekilde yazma niyeti asırlar boyu devam ederek Arap yazısının sanat hüviyeti kazanmasına sebep olmuştur.

Dört Halife Dönemi'nde başlayan fetih hareketleri, İslam coğrafyasını genişletti. IV. halife Hz. Ali döneminde bugünkü Irak sınırlarında bulunan Kûfe şehri kültür ve sanat alanında en önemli şehirler arasındaydı. Yeni Müslüman olan toplumlara Kûfe'de istinsah edilen Mushaflar hediye olarak gönderilmiştir. Mushaflarda kullanılan yazı çeşidinin şehrin ismine nispetle Kûfe'ye ait veya Kûfe'den anlamlarına gelen kûfî olarak adlandırıldığı düşünülmektedir. ${ }^{2}$ Ancak bu yazı çeşidinin Kûfe'den çok önce kullanıldığı bilindiği için bazı araștırmacılar Kûfî adlandırmasının hicrî V. yüzyıldan sonra olduğunu ileri sürmektedirler. ${ }^{3}$ Kûfî yazısı yazıldığı coğrafyaya göre isimler alır. Temelde aynı karakterde olmakla birlikte bazı nüanslarla birbirlerinden ayrılan bu yazı türleri Fâtımî Kûfîsi, Eyyûbî Kûfîsi, Memlük Kûfîsi, Endülüs Kûfîsi'dir. Emevîler'in son devirlerindeki kûfî yazılarında sertlik ve keskinliğin kaybolduğu görülmektedir. Abbâsîler devrinde vezirliğinin yanında usta bir de hattat olan İbn Mukle (ö. 328/940) tarafından yapılan bazı yenilikler neticesinde yazı belli kurallara bağlanmış ve Aklâm-ı sitte denilen altı yazı çeşidi meydana gelmiștir. ${ }^{4}$ Bunlar sülüs, nesih, muhakkak, reyhani, tevki ve rikâ'dır. Aklâm-ı sitte'nin teșekkülünde çok önemli rol oynayan başka bir isim ise İbn'ül Bevvab'tır (ö. 413/1022). İbn Mukle'den yaklaşık bir asır sonra eser üretmiş olan İbnü'l Bevvab'ın, İbn Mukle'den kalan yarım bir eseri tamamladığında iki hattatın yazıları ayırt edilmeyecek kadar kudretli bir hattat olduğu bilinmektedir. ${ }^{5}$ Hat sanatında en önemli uygulamalardan biri olan kalemin eğik şekilde kesilmesi Yâkût elMüsta’sımî (ö. 698/1299) tarafından yapılmıștır. Kalemin eğik kesilmesinden sonra tüm yazı çeşitlerinin estetiği değişmiş, yazı sanat yolunda önemli bir yol

1 Mahmud Bedreddin Yazır, Medeniyet Âleminde Yazı ve İslâm Medeniyetinde Kalem Güzeli (Ankara: Diyanet Isşleri Başkanlı̆̆ı Yayınları, 1981), 122.

2 Yazır, Medeniyet Âleminde Yazı ve İslâm Medeniyetinde Kalem Güzeli, 68.

Muhittin Serin, Hat Sanatı ve Meșhur Hattatlar (İstanbul: Kubbealtı Neşriyat, 2008), 69.

Nihad M. Çetin, "Aklam-ı Sitte", Türkiye Diyanet Vakfi İslâm Ansiklopedisi (İstanbul: TDV Yayınları, 1989), 2/277.

5 Muhittin Serin, "İbn'ül Bevvab", Türkiye Diyanet Vakfi İslâm Ansiklopedisi (İstanbul: TDV Yayınları, 1999), 20/534. 
almıştır. Yakût aynı zamanda harflerin ölçülerini kalemin noktasıyla belirleyerek günümüzde de kullandığımız kadim metodu geliştirmiştir. ${ }^{6}$

İslâmiyet'in Arap yarımadasından farklı coğrafyalara yayılmasıyla birlikte, Asya'dan Avrupa'ya birçok farklı millet İslam medeniyetine katkılar sunmuştur. Bu milletlerin başında Türkler gelmektedir. Türkler Müslüman olduktan sonra Arap alfabesini kullanmışlardır. Anadolu Selçukluları döneminde Türklerin Anadolu'ya girmesiyle birlikte Aklam-ı sitte yazı çeşitleri Mushaf ve diğer yazma eserlerde görülmektedir. Anadolu Selçukluları döneminin anıtsal mimari eserlerinde hem kitabe hem de tezyinat amaçlı Selçuklu sülüsü ve Kûfî yazı çeşitlerinin kullanıldığı görülmektedir. Beylikler döneminde Anadolu Selçuklu hat sanatının tüm özellikleri devam etmiştir. Ancak bu dönemde celî sülüs yazının ma'kıli ve kûfî yazıya nispetle daha çok tercih edildiği görülmektedir.

Erken Osmanlı hat sanatında Anadolu Selçuklu etkileri devam etmiş, İstanbul'un fethiyle (1453) birçok alanda yapılan köklü değişiklikler sanatı da etkilemiş ve bu dönem hat sanatının en parlak dönemlerinden biri olmuştur. Fatih Camii ve Topkapı Sarayı Bâb-ı Hümâyun yazılarının hattatı Ali b. Yahya Sofînin (ö. 882/1478) özellikle Topkapı Sarayı kapısındaki müsenna yazısı dönemin zevkini ve yazının ulaştığı estetiği göstermesi bakımından dikkate değerdir. (Resim 3).

Fatih'in oğlu II. Beyazıd'ın Amasya'daki şehzadeliğinde hat hocası, kendisinden sonra Hat sanatında bir Türk ekolü oluşturacak Şeyh Hamdullah (ö. 840/1437) idi. II. Beyazıd tahta geçișinden kısa bir süre sonra hocasının İstanbul'a geldiği bilinmektedir. II. Beyazıd hattat bir sultan olduğu için yazıya karşı ilgisi oldukça fazla idi. Kendisi hazinede bulunan Yakût el-Müsta'sımi'ye ait yazıları incelemesi için hocasına vermiş, kaynaklarda geçen ifadeye göre 'Bu tarzdan gayri bir vadi ihtirâ olunsaydı iyi olurdu.' diyerek Şeyh Hamdullah'ın üslûbunu bulmasına ve dahası yazıya bir Türk üslûbu kazandırılmasına vesile olmuştur. Şeyh Hamdullah'ın Türk hat sanatında yaptı̆̆ı ıslahatlar uzun yıllar boyunca talebeleri ve onların da talebeleri tarafindan benimsenerek devam ettirilmiştir. Şeyh'in yazıya getirdiği yenilikler ve ortaya koyduğu kaideler Türk hat sanatının temelini oluşturmuş, gelecek yıllarda yeni ekoller oluşmasına rağmen Şeyh'in çizdiği yol varlığını devam ettirmiştir.

Şeyh Hamdullah'ın İstanbul'da olduğu dönemlerde yazı sanatına yeni başladığı tahmin edilen başka bir ekol sahibi isim de Ahmed Karahisârî (ö. 963/1556) idi. Karahisârî, imzasında hocasının adının Esedullah-ı Kirmânî olduğunu yazmaktadır. Tasarım yönünden çok mahir bir hattattır. Karahisârî'den günümüze ulaşan eserlerin başında Kanunî Sultan Süleyman için yazdığı Mushaf ve müselsel besmele ilk akla gelenlerdir. Üvey evladı ve talebesi olan Hasan Çelebi, Karahisârî ekolünün başta gelen takipçisidir. Süleymaniye Camii kitabesi ve çini üzerindeki yazılar ile Edirne Selimiye Camii çini üzerindeki

6 Muhittin Serin, "Yâkût el-Müsta'sımî", Türkiye Diyanet Vakfi İslâm Ansiklopedisi (İstanbul: TDV Yayınları, 2013), 43/291. 
yazılar Hasan Çelebi'ye aittir. ${ }^{7} \quad$ Hasan Çelebi ustalık döneminde Karahisârî ekolünden ayrılarak, Şeyh ekolünde eserler vermiștir.8 ${ }^{8}$

Hafız Osman (ö.1110/1698), Şeyh Hamdullah ekolünün temsilcilerinden meşk etmiş ve kendisi tam anlamıyla Şeyh ekolü temsilcisi olmuş bir hattattı. Hafız Osman, Şeyh Hamdullah'ın yazılarını çok iyi incelemiş ve en beğenilen harfleri kullanmıştır. ${ }^{9}$ Türk hat sanatında Şeyh Hamdullah, Yâkût-el Müsta'sımî'nin nesih yazının sıkıșık nizamını dengelemiș, Hafız Osman ise Şeyh'teki kûfi yazının etkilerini tamamen kaldırıp özellikle sülüs ve nesih yazı çeşitlerine canlılık getirmiștir. ${ }^{10}$ Şeyh Hamdullah ve Hafız Osman'ın yaptığı bu yenilikler kitap sanatları çerçevesinde kendini göstermiştir. Bununla beraber mimariye ait yazılarda önemli bir değişiklik gözükmemektedir.

Mustafa Râkım Efendi (1758-1826) kendisi gibi hattat olan ağabeyi İsmail Zühdî'den (ö.1806) meşk etmiştir. Hafız Osman'ın talebesi ve ekolünün önemli temsilcilerinden biri olan İsmail Zühdî Efendi, Mustafa Râkım'ın yetişmesinde büyük öneme sahiptir. Mustafa Râkım, ağabeyinin ve Hafız Osman'ın yazılarını çok iyi talim etmiștir. Mustafa Rakım Efendi'ye kadar mimaride kullanılan celi sülüs yazısı Fatih döneminde en kudretli dönemini yaşamıştır ancak Şeyh Hamdullah ve Hafız Osman'ın gayretlerine rağmen henüz arzu edilen noktaya ulaşmamıştır. Mustafa Râkım'a kadar celi sülüs kitabeler, harfler ve bazı kelimeler çok güzel yazılmasına rağmen genel bir satır nizamı yoktur. ${ }^{11}$ Mustafa Râkım'ın hat sanatında yaptığı birçok katkı bulunmakla beraber bunların arasında en önemlisi celi sülüs yazıda satır nizamını en güzel șekilde ortaya koymasıdır. Özellikle dikey harflerin boylarını, harflerin estetiğini bozmadan kısaltıp uzatması ve satırda nizami olarak kullanması hemen göze çarpar. Mustafa Râkım Efendi'nin yazmış olduğu kitabeler arasında Nakşıdil Vâlide Sultan Türbesi'nin yazıları ve Nusretiye Camii kuşak yazıları en önemlileridir.

Mustafa Râkım Efendi'nin açtığı yolda devam eden ve daha sonra başka bir ekol vücuda getiren diğer hattat Kazasker Mustafa İzzet'tir (ö. 1293/1876). Kazasker Mustafa aklam-ı sitte'de Hafız Osman ekolünü benimsemiş, celi sülüste ise Mustafa Râkım ekolünde eserler üretmiștir. Sultan Abdülmecid'e yazı hocası olduğu zaman, sultanın isteğiyle Mahmud Celâleddin ekolünde eserler de vermiștir. Onun bu dönemi tam anlamıyla Mahmud Celâleddin ile Mustafa Râkım arasında bir yer tutmuş ve kendine has eserler üretmiştir. Kazasker Mustafa İzzet'in birçok eseri müze ve özel koleksiyonlardadır. Mimarideki eserleri arasında Ayasofya Camii'ndeki çehâr yâr-ı güzin yazıları ve kubbe yazısı, Hırka-i Şerif Camii yazıları ve Yahya Efendi Camii kubbe yazısı en çok bilenen yazılarıdır. Kazasker'in talebeleri arasında, Şefik Bey (ö.1297/1880), Alâeddin Bey (ö. 1305/1887), Muhsinzâde Abdullah (ö.1317/1899) ve Hasan Riza Efendi en meşhur olanlarıdır. Hattat Nuri Korman (ö.1371/1951), Kazasker'in talebeleri olan Alâeddin Bey ile Muhsinzâde Abdullah Bey'in talebesi olmakla Kazasker Mustafa İzzet ekolünün son temsilcilerindendir.

Muhittin Serin, Hat Sanatı ve Meșhur Hattatlar, 114.

8 Uğur Derman, "Hasan Çelebi", Türkiye Diyanet Vakfi İslâm Ansiklopedisi (İstanbul: TDV Yayınları, 1997), 16/313.

Ali Alparslan, Osmanlı Hat Sanatı Tarihi (İstanbul: YKY Yayınları, 2007), 66.

10 Alparslan, Osmanlı Hat Sanatı Tarihi, 66.

11 Alparslan, Osmanlı Hat Sanatı Tarihi, 118. 
Osmanlı devrinde hat sanatı hoca talebe ilişkisiyle devam etmiştir. Resmî bir kurumda hat eğitiminin verilmesi ancak XIX. yüzyılın başlarında mümkün olmuştur. Rüştiye ve idadilerde temel seviyede verilen hat eğitiminin yanında II. Abdülhamid döneminde Sadrazam Ahmed Cevad Paşa öncülüğünde, Sami Efendi'nin de hat hocası olduğu Dîvân-ı Hümâyun içerisinde Ta'lim-i Hat Şubesi'nin kurulmasıyla, daha ileri seviyelerde talim edilmiştir; ancak umuma açık olmayan bu şube Ahmed Cevad Paşa'nın sadrazamlıktan ayrılmasıyla birlikte önemini kaybetmiştir.

II. Meşrutiyet'in ilânından sonra resmî olarak hat eğitimi veren bir kurumun açılması gerektiği konuşulmuş ve 20 Kasım 1915 yılında Medrestü'l-hattâtîn adıyla bir okul açılmıştır. Okul bünyesinde hat, tezhip, minyatür, ebru, ahar ve cilt dersleri verilmiştir. Harf inkılabıyla birlikte okul kapatılmış, hat sanatı eski değerini kaybetmiş, sosyal hayatın bir parçası olmaktan çıkıp sadece dinî mimarinin bir unsuru olarak devam etmiştir.

Okulun ilk mezunları arasında Sami Efendi'nin talebesi, okulun ebru ve ahar hocası olan Necmeddin Okyay ile Mustafa Halim Özyazıcı bulunmaktadır. Sami Efendi'nin talebeleri olan Kâmil Akdik, İsmail Hakkı Altunbezer ve Necmeddin Okyay gibi kıymetli hattatlar sayesinde Osmanlı İmparatorluğu ile Türkiye Cumhuriyeti arasında köprü kurulmuştur. Necmeddin Okyay'ın talebelerinden Ali Alparslan ve Uğur Derman hat sanatı tarihiyle ilgili birçok kitap, makale ve bildiriye imza atmıştır. Yapılan bu akademik çalıșmalar sayesinde Türk hat sanatı tarihinin seyrini net bir şekilde inceleme imkânına sahibiz.

Hat sanatı icrası bakımından ise Hamid Aytaç'ın önemi büyüktür. Mustafa Halim Özyazıcı'nın vefatıyla, öğrencilerinin Hamid Aytaç'a devam ettiği bilinmektedir. Bugün yaşayan neredeyse tüm hattatların hocası hocaların hocası vasfiyla anılan Hamid Aytaç'tır.

\section{Mimari Yapılarda Hat Sanatının Sergilenme Usûlü}

Hat sanatı mimarinin ayrılmaz bir parçası olarak yapılarda kitabe, taç kapı, kubbe, eyvan ve pencere alınlıkları gibi kısımlara uygulanmıştır. Emevîler döneminde Mescid-i Nebevî’nin genişletilmesi esnasında Hattat Hâlid b. Ebü'lHeyyâc'ın kıble duvarına Şems suresinden başlayarak Kur'an'ın sonuna kadar yazdığı yazı ilk celî yazı örneği olarak gösterilir.12 Emevilerden sonra Abbasiler, Büyük Selçuklular, Anadolu Selçukluları, Beylikler Dönemi, Osmanlılar ve Cumhuriyet dönemiyle birlikte Anadolu coğrafyasında mimari eserlerde hat sanatı yaygın bir şekilde kullanılmıştır.

Mimari yapılarda hat sanatının kullanıldığı yerlerin başında kitabeler gelmektedir. Kitabeler sadece yapının banisinin, mimarının ve yapılıș tarihinin yazıldığı eserler olmayıp adeta bir edebi metin ile hat sanatının bütünleştiği sanat eserleridir. Kitabeler, özellikle tarih kısmında ebced ${ }^{13}$ hesabıyla tarih düşürülerek başka bir edebi sanat unsuruna vücut vermiştir. Türk İslam medeniyetinde camilerin inşa kitabesine ilave olarak taç kapı, mihrap, minber,

12 Serin, Hat Sanatı ve Meşhur Hattatlar, 50.

13 Arap elifbasında her bir harfe sayısal bir değer verilerek, kelime ve cümlelerin sayısal değerini hesaplama ve çıkan sonuçtan anlam çıkartma işlemidir. 
kubbe ve kuşaklara hat sanatı uygulanmıştır. Medreselerde taç kapı ve iç kısımda, çeşmelerde ise alınlık kısmında kitabeler bulunmaktadır. Kitabelerde kullanılan ibareler zaman içinde farklılık göstermesine rağmen yapıyla ilişkileri her zaman devam etmiştir. Özellikle camiler çini, taş ve ahşap gibi farklı malzemelerle tezyinatın ve özellikle hat sanatının uyum içinde bir bütün olarak görülebildiği yegâne yapılardır.

İslam medeniyetinde șehirler cuma mescitleri veya ulucami olarak bilinen merkezi cami etrafında şekillenmiştir. Şehir merkezleri, caminin çevresinde alışveriş, eğitim kurumları, han ve hamam gibi yapılarla toplumun ihtiyaçlarına göre genişleyerek büyümüştür. Yapılarının baniliği devletin yüksek kademeli yöneticileri tarafından üstlenilmiştir. Hükümdarlar ve yüksek bürokratlar sanatı saraylarına hasretmemiş, cami, medrese ve çeşme gibi kamusal alanlarda da hiçbir masraftan kaçınmayarak dönemin usta sanatkârlarıyla çalışmışlardır. Camiler yapısı gereği toplumun tüm üyelerine açık alanlar olduğu için kitlesel olarak sanat anlayışını etkilemiştir. Bugün daha çok Batı sanatlarıyla ilgili olarak kullanılan "kamusal alanlarda sanat" kavramı yüzyıllardır fiilî olarak İslam sanatlarıyla yașatılmaktadır. Bu haliyle hat sanatı toplumun belirli kesimine ait bir sanatı olmamış, toplumun tüm kesimini kucaklayan ve kişinin kendi sanat anlayışı ölçüsünde zevk aldığı bir sanat alanı olmuştur.

Mimari kitabelerin beraberinde hat sanatının uygulandı̆̆ı diğer alanlar arasında mezar taşları gelmektedir. Ahlat Selçuklu Mezarlığı, Anadolu mezar taşı geleneğinin başlangıcı sayabileceğimiz yerdir. Ahlat mezar taşlarını önemli kılan başka bir unsur da mezar taşlarında bulunan sanatkâr kitabeleri yani imzalarıdır. Bu sanatkârlar Konya Alâaddin Camii'nin minberini yapmıș olan elHac Mekki b. el-Hılâtî, Divriği Ulu Camii ile Darüşşifasını yapmış olan Hûrremşah el-Hılâtî, Tercan'daki Mama Hatun Türbesi'nin mimarı Ebu'n-Nema b. Mufaddalu'l-Ahval el-Hılâtî, Gevaș Halime Hatun Kümbeti'nin ustası Esed b. Havend el-Hilâtî, Kayseri-Nevșehir yolu üzerindeki Alay Han'ını yapan Ahlatlı sanatkârlardır. ${ }^{14}$

Türbe ve kümbetlerde bulunan mezar taşlarıyla beraber, bir yapının kubbe, kuşak, sanduka ve pûşîde örtülerindeki yazılar hat sanatının uygulandığı diğer yerler arasındadır.

Anadolu Selçuklu dönemine ait anıtsal yapıların en önemlileri dönemin başkenti Konya'da bulunmaktadır. Dönemin önemli yapıları arasında bulunan İnce Minareli Medrese ile Karatay Medresesi'nin taç kapısı hat sanatı açısından oldukça zengindir. Taş işçiliğinin ustalıkla uygulandığı bu eserler kapalı bir alanda olmadığı gibi büyüklügüuyle uzaktan fark edilecek ölçüde ve yakınlaştığınızda hat sanatının detayları görülecek zarifliktedir. İnce Minareli Medrese'nin taç kapısında Fetih Suresi'nin ilk 13 ayeti, Yasin Suresi'nin 1-31. Ayetleri taşa oyma usulüyle yazılmıştır. (Resim 1). Karatay Medresesi'nin taç kapısındaki inşa kitabesinde kısa hadislerden oluşan bir tasarım yapılmıştır. ${ }^{15}$ (Resim 2).

14 Cansu Reisoğlu, Ahlat Meydan Mezarlığı'ndaki Hacı Miran Bin Yusuf'a Ait Mezar Tașları (Van: Yüzüncü Yıl Üniversitesi, Sosyal Bilimler Enstitüsü, Yüksek Lisans Tezi, 2016), 25.

15 Ahmet Gedik, “Karatay Medresesi Taçkapısı'ndaki Celî Yazıların Hat San'atı Bakımından Değerlendirilmesi”, İstem, 3 (Aralık 2004), 171. 
Osmanlı dönemine ait önemli kitabelerin başında Fatih Sultan Mehmed'in (ö.1481) İstanbul'u fethinden sonra yaptırdığı Topkapı Sarayı Bab-ı Hümayun kitabesi gösterilir. (Resim 3). Ali bin Yahyâ es-Sûfî (?) tarafından yazılmış ${ }^{16}$ bu kitabe XV. yüzyılda Türk hattatların ulaştığı seviyeyi gözler önüne sermektedir.

Türk hat ekolünün kurulmasında önemli rolü olan, Sultan II. Bayezid'in (ö.1512) hat hocası Şeyh Hamdullah'ın (ö.1520) yaptığı yenilikler ile hat sanatı Türk şivesi kazanmış oldu. ${ }^{17}$ "Kur'an-ı Kerim Mekke ve Medine'de nazil oldu, Mısır'da okundu, İstanbul'da yazıldı” sözünün meşhur olmasının sebebi özellikle Osmanlılar döneminde hat sanatının neșvünema bulmasıdır.

XIX. yüzylla gelindiğinde celîn ${ }^{18}$ yazılarda önemli değişimler olmuştur. Mustafa Râkım Efendi'nin (1758-1826) Nusretiye Camii kuşak yazısı ile tuğrada yaptığı yenilikler bu değișimlerin en göze çarpanlarıdır. Râkım Efendi özellikle celî sülüs yazıda dikey harflerin yatay harflerle olan nispetlerini ideal noktaya getirmeyi başarmıştır. ${ }^{19}$

XX. yüzyılın başlarında Sami Efendi (1838-1912) celî sülüs, celî ta'lik ve sarayın resmi metinlerinde kullanılan celî divanî yazı şeklinin son halini almasında büyük başarı göstermiștir. ${ }^{20}$ Yukarıda zikredilen mimari yapılara ilave olarak II. Abdülhamid (1876-1909) döneminde nezaretlerin ve yeni eğitim kurumlarının açılmasıyla birlikte ilgili yapıların kitabeleri de hat sanatı örneklerini oluşturmaktadır.

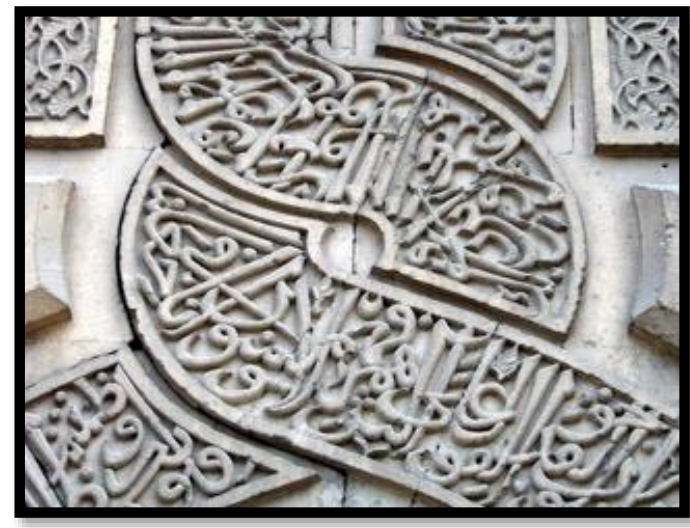

Resim 1 - Ince Minareli Medrese Taç Kapısı Detay (https://www.flickr.com/photos/galpay/3785191357/),

Erişim 1 Haziran 2021

16 Ekrem Hakkı Ayverdi, Fâtih Devri Hattatları ve Hat Sanatı (İstanbul: Fethi Derneği Yayınları, 1953), 16.

17 Nefeszâde İbrâhim, Gülzâr-ı Savâb (Neşre hazırlayan Kilisli Muallim Rif'at), (İstanbul: Güzel Sanatlar Akademisi Neşriyat, 1939), 49.

18 Geniş bir kalem ile yazıların iri yazılmasına celî denir. Celî Sülüs, Celî Ta'lik ve Celî Divanî gibi.

19 Alparslan, Osmanlı Hat Sanatı Tarihi, 119.

20 Alparslan, Osmanlı Hat Sanatı Tarihi, 91. 


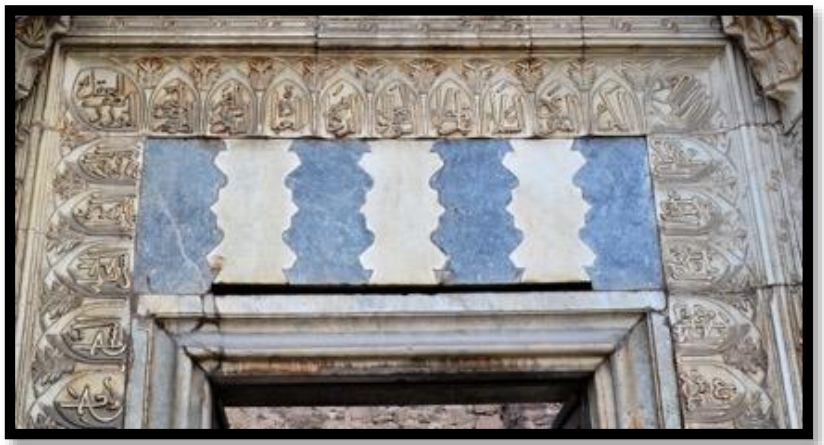

Resim 2 - Karatay Medresesi Taç Kapısı Detay (https://www.flickr.com/photos/smyeo/14964681076/), Erişim 1 Haziran 2021

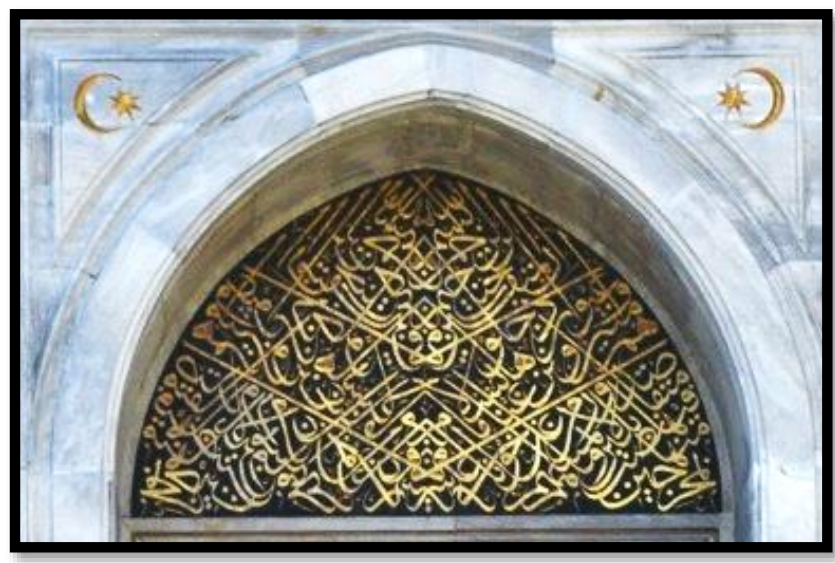

Resim 3 - Topkapı Sarayı Bab-ı Humayun Kitabesi (https://www.flickr.com/photos/29302734@N02/8391596050/), Erişim 1 Haziran 2021

\section{Levha Olarak Hat Sanatı}

Hat sanatında levha yazımının hangi tarihte başladığı net olarak bilinmemektedir. Bilinen en eski örnek duvara asılması için kâğıt üzerine yazılarak hazırlanan Hilye-i Şerif levhalarıdır. Hilye-i Şerif metni Resul-i Ekrem'in vasıflarının yazıldığı metinlerdir. Hilye-i Şerif metni ilk kez XVII. yüzyılın sonlarında Hattat Hafız Osman (ö.1698) tarafından levha olarak oluşturulmuştur. ${ }^{21}$ (Resim 4) Hafız Osman öncesinde hilye örnekleri yazma eserlerde ve insanların cevşen olarak üzerinde taşıyabileceği şekilde karşımıza çıkmaktadır. Herhangi bir dinî dayanağı tespit edilmemesine rağmen Hilye-i Şerif metnini yanında taşıyan kişilerin her türlü musibetlerden korunacağına, bulunduğu ev ve işyerinin felâkete uğramayacağına inanılması levha olarak

21 Uğur Derman, "Hilye”, Türkiye Diyanet Vakfı Íslâm Ansiklopedisi (İstanbul: TDV Yayınları, 1998), $18 / 47$. 
hazırlanmasında önemli bir rol oynamış olabilir. Resul-i Ekrem'in resmedilmesi hoş karşılanmadığı için hilyeler bir anlamda soyut resim olarak düşünülebilir.

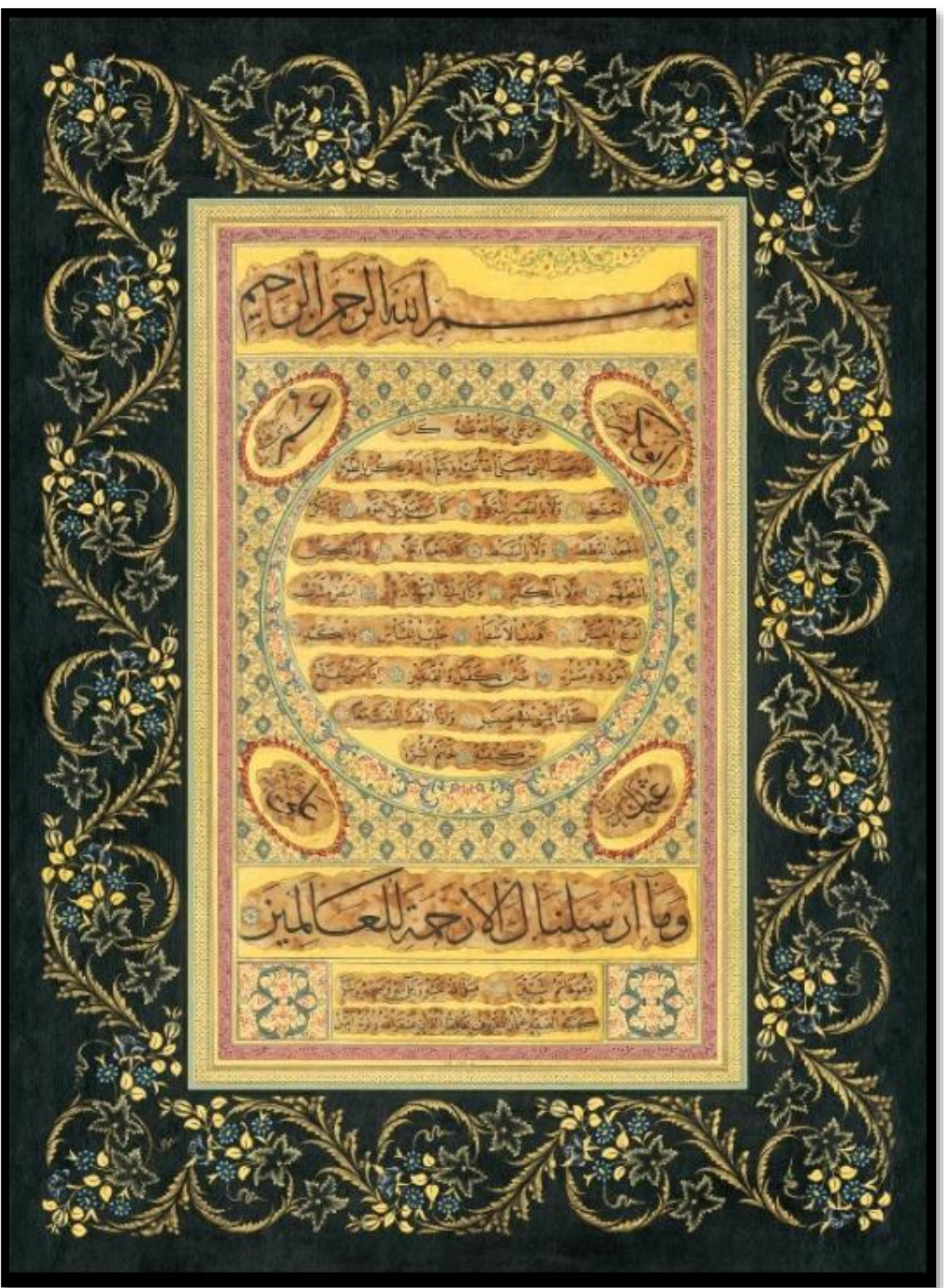

Resim 4 - Hilye-i Şerif, Hafiz Osman (ketebe.org/sanatkar/hafiz-osman-323), 
Hilye levhalarını bir başlangıç olarak düşündüğümüzde diğer levhaların ibareleri genellikle ayet, hadis, dua, kelam-ı kibar, kelime-i tevhit, besmele-i şerif gibi metinler olarak karşımıza çıkmaktadır. Hattat Hafız Osman'dan sonraki dönemde yaşamış hattatların Hilye-i Şerif'e ilave olarak hazırladıkları levhalar bu minvaldedir. Bu levhaların cami, mescit, ev veya işyerine asılmak amacıyla yapılmış olduğu aşikardır.

Osmanlı padișahlarının hat sanatıyla ilgilendikleri ve bazı padişahların icazet alarak eser verdikleri bilinmektedir. Genellikle levha olarak hazırlanan bu yazılar cami ve mescitlere hediye edilmek üzere hazırlanmıştır. (Resim 5) Üsküdar III. Ahmet Çeşmesi'nin kitabesinin bizzat Sultan III. Ahmet tarafından yazıldığ bilinmektedir.

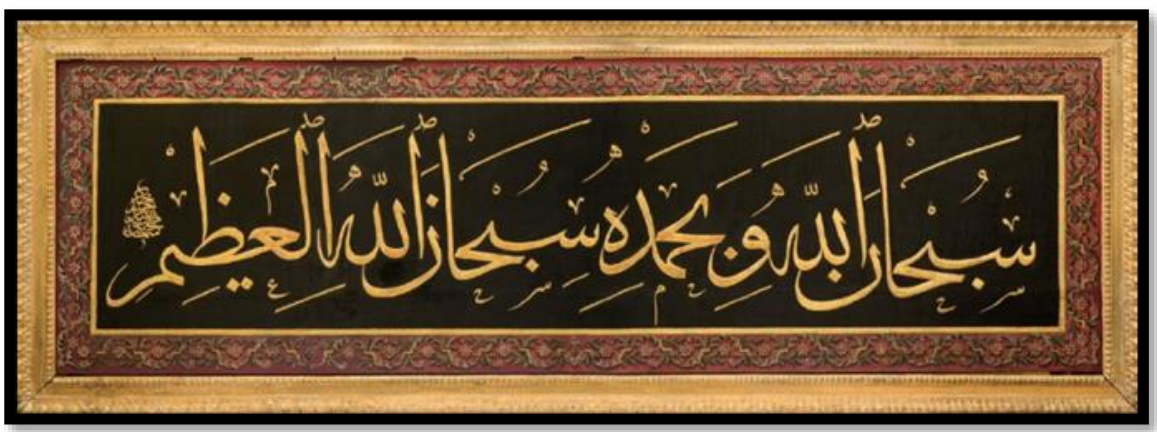

Resim 5 - Sultan II. Mahmud Celi Sülüs Levha (ketebe.org/sanatkar/sultan-mahmud-887), Erişim 26 Haziran 2021

Hat levhalarının sıklıkla görüldüğü yerler arasında tekke ve zaviyeler bulunmaktadır. Tekke yazıları olarak hat sanatı literatürüne giren levhaların içeriği Âl-i abâ22 isimleri, tarikatın pirinin adı, zikir ile ilgili ayet ve hadislerdir. Tekke yazıları arasında klasik hat kaidelerine uymayıp sadece tekke yazıları alanında değerlendirilenler olduğu gibi hat sanatının tüm kaidelerine uyan sanatlı yazılar da mevcuttur. (Resim 6).

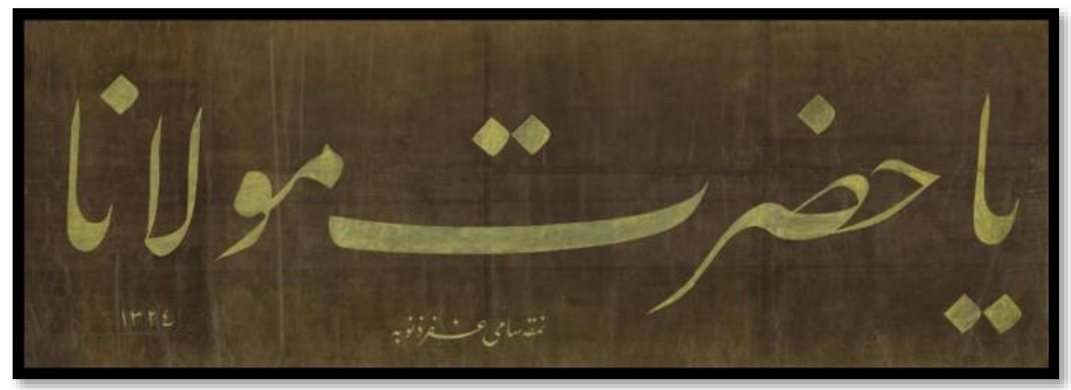

Resim 6 - Sami Efendi Celi Ta'lik (ketebe.org/sanatkar/sami-efendi-747), Erişim 26 Haziran 2021

22 Hz. Muhammed'in abâsının altındakiler Hz. Ali, Hz. Fatima, Hz. Hasan ve Hz. Hüseyin. 
Çehar yar-i güzin yazıları cami mimarisinde inşa kitabesi, kubbe, mihrap, minber ve kuşak yazılarına ilave olarak ilerleyen yüzyıllarda levha olarak asılmaya başlamıştır. Anadolu Selçuklu döneminde genellikle kubbe merkezinde çini üzerine yazılan bu yazılar Osmanlı döneminde çini malzeme olarak devam etmiş ancak levha yazımının yoğunlaştığı dönemde levha olarak hazırlanmaya başlamıştır. Bu yazıların en meşhuru bugün Ayasofya Camii'ndeki Kazasker Mustafa İzzet'e ait ve çapı 7.5 metre olan çehar yar-i güzin yazılarıdır. (Resim 7).

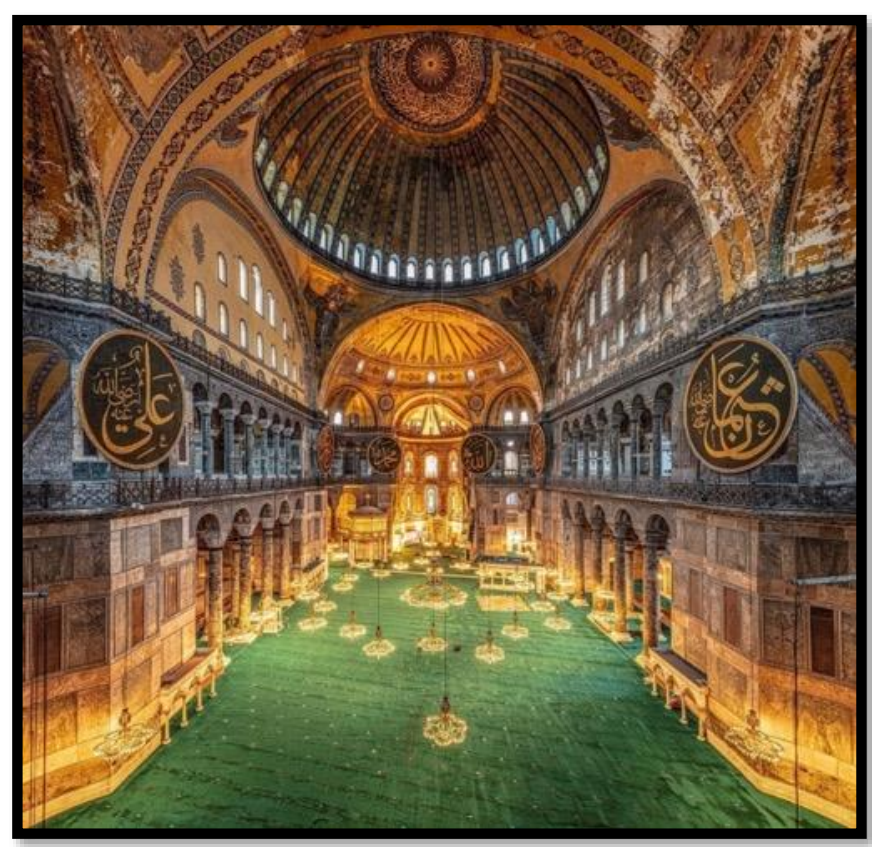

Resim 7- Ayasofya Camii (Mehmet Özçay),

Levha olarak Hilye-i Şerif ve çehar yar-i güzin yazılarından sonra en çok oluşturulan form kıta'lardır. Kıtalar muhakkak-reyhani, tevki-rikaa, sülüs-nesih yazı çeşitleriyle birlikte yazılmıştır. Bu örnekler arasında en yaygın olanları ise sülüs-nesih yazı çeşidiyle yazılmış kıtalardır. Kıtalarda sülüs yazı ile ayet-i kerime veya hadis-i şerifin ana metni, sonrasında ayet ise ayetin devamı, dua kısmı ve ketebe satırı, metin hadis-i șerif ise salavat, hadis-i şerif metni, dua kısmı ve ketebe satırı bulunmaktadır. Nesih satırların sağında ve solunda tezhip için boş bırakılan kısımlara "koltuk" denilmektedir. Kıtalar mukavvaya yapıştırılır ve koltuk kısımlarıyla birlikte kenarları tezhiplenir. Bir tarafa eğilmiş yatay olarak oluşturulan kıtalara, bir tarafa eğilmiş anlamına gelen mâil kıta denilmektedir. Hat sanatında icazetler genellikle kıta formunda hazırlanmaktadır. Kıtaların ilk devirlerde yazma eserler içinde bulunduğu daha sonra murakka olarak hazırlandığı ve nihayet tek başına bir levha olarak asıldığı bilinmektedir. (Resim 8). 


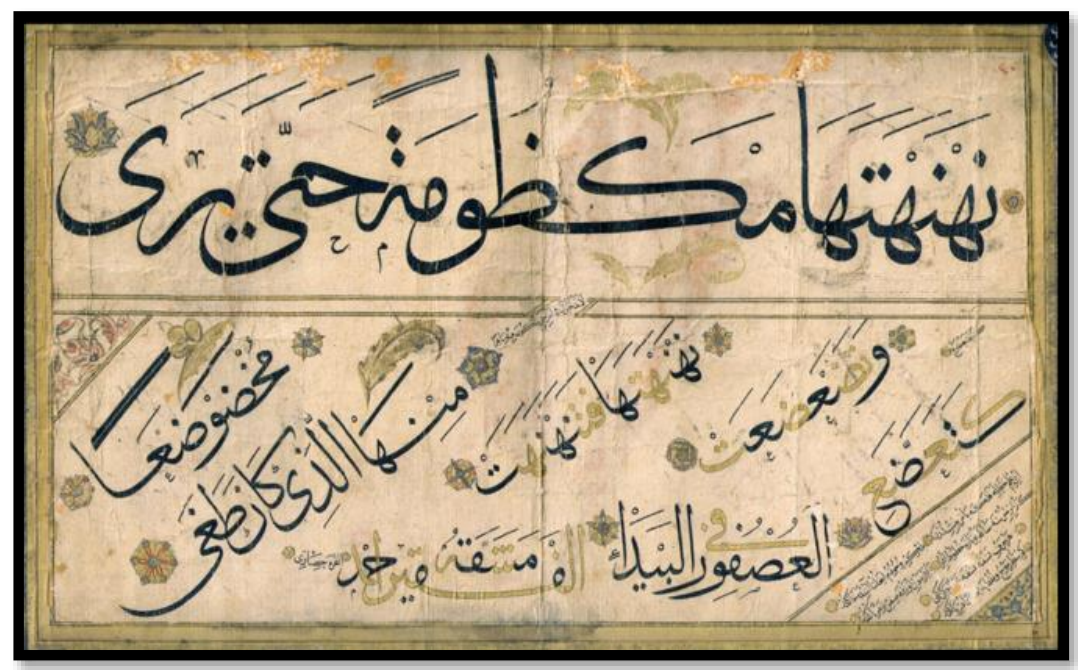

Resim 8 - Ahmed Karahisârî (ketebe.org/sanatkar/ahmed-karahisari-75),

Erişim 26 Haziran 2021

Hat sanatındaki levha türlerine bir örnek de hutût-ı mütenevvia olarak hazırlanan yazılardır. Bu levhalarda hattat yazmış olduğu tüm yazı çeşitleriyle bir levha hazırlar. Genellikle düz satır halinde yazılan bu yazılarda, her bir yazı çeşidiyle aynı metin tekrar edilebildiği gibi baștan başlayarak son satıra kadar devam eden bir metin de yazabilmektedir. Bu anlayış tasarım olarak bazı yenilikler doğurmuştur. Bu tür levhalar hat sanatında farklı yazıların birlikte kullanılmasıyla oluşan özgün tasarımlar olușturulmasına imkan vermiștir. Hattat Aziz Efendi (1872-1934) bu anlayışı hilye-i şerif levhalarında kullanarak yenilikçi tasarımlar oluşturmuştur. Günümüz hattatlarından Abdurrahman Depeler, levhalarında farklı yazı çeşitleriyle bu yönde eser üreterek dikkat çekmektedir. (Resim 9).

Hat sanatında asırlardır siyah is mürekkebi kullanılmış, levhanın renkleri ise tezhip sanatıyla oluşturulmuştur. İs mürekkebi haricinde görebileceğimiz yazılar altın ile doldurulan zerendud yazılar olabilir. Teknolojinin ilerlemesi ve farklı malzemelerin hat sanatında uygulanmasıyla beraber renkli mürekkepler tercih edilmeye başlamıştır. Renkli mürekkepli levhaların öncüsü olarak değerlendirebileceğimiz isim Hattat Mehmet Özçay'dır. Mehmet Özçay ve kardeşi Osman Özçay levhalarında renkli mürekkebi en uygun şekilde kullanarak hat sanatına ve hattatlara bir alternatif sunmuştur.

Levha olarak değerlendirebileceğimiz bir başka tür ise karalamalardır. Genellikle hattatın elinin soğumaması için ve temrin anlamında çalıştığı metnin harflerini, harf birleșimlerini ve kelimeleri yazmasına ve bununla oluşan yazılara karalama denilmiştir. İlk devirlerde bir tasarım anlayışı ile yapılan bu karalamalar günümüzde bir levha gibi tasarlanarak yazılmaktadır. 
Resim 7 - Abdurrahman Depeler (ketebe.org/sanatkar/abdurrahman-depeler-2091),

Erişim 26 Haziran 2021

\section{Dijital Mecrada Hat Sanatı}

Türkiye'de internet ilk kez 1993'te kullanılmaya başlanmıștır. ${ }^{23}$ Yaygın bir şekilde kullanılmaya başlanması ise 2000'li yıllara tekabül etmektedir. Geniş bantlı internet (adsl) ise 2005 yılında aktif olarak kullanılmaya başlamıştır. 2007 yılında yeni nesil telefonlar yani akıllı telefonların yaygınlaşmasıyla birlikte internet hayatımızın vazgeçilmez unsurlarından biri olmuştur.

İnternete erişimin kolay ve hızlı olmasıyla birlikte yeni akım medya olarak değerlendirilen haber siteleri ve sosyal medya olarak adlandırılan mecralar insanların fazlaca zaman harcadığı yerler olmuştur.

Londra merkezli We Are Social oluşumu her yll dijital ortamın verilerini paylaștığı raporlar yayınlamaktadır. 2020 verilerine göre Türkiye'de 16-64 yaş aralığındaki kişilerin günlük ortalama 7 saat 29 dakika sosyal medya mecralarında vakit geçirdiği görülmektedir. ${ }^{24} \mathrm{Bu}$ sosyal medya mecraları Facebook, Instagram, Twitter, Youtube ve birçok forum siteleridir. Yine aynı raporun verilerine göre Türkiye'de 38 milyon kullanıcı Instagram'ı, 37 milyon kullanıcı Facebook'u ve 11.8 milyon kullanıcı ise Twitter'ı takip etmektedir.

23 Hakan Can Altunay, Türkiye Örneğinde İnternet Ağ Altyapısının Tıkanıklık Analizi (Sakarya: Sakarya Üniversitesi, Fen Bilimler Enstitüsü, Yüksek Lisans Tezi, 2014), 9.

24 We Are Social, We Are Social Ltd,"Digital In 2020". Erişim 15 Haziran 2021. 
Genel anlamda sanat eserlerinin sergilendiği yerler müzeler, sergi salonları ve özel sanat galerileri aracılığıyla olmaktadır. Günümüzde internetin yaygın olarak kullanılmasıyla birlikte sanatçılar kişisel internet siteleri, sosyal medya hesapları ve müstakil olarak bir sergi oluşturmaya imkan veren siteler aracılığıla eserlerini sergilemektedir.

Sanatçların kişisel internet sayfalarında, sanatçının özgeçmişi, iletişim bilgileri, şahsi bilgileri ve sanat eserlerini sergilediği bölümler bulunmaktadır. $\mathrm{Bu}$ bölümler fotoğraf albümü, video ve animasyonlar gibi dijital içeriklerden oluşmaktadır. Kişisel internet sitelerindeki etkileşim tek taraflı olduğundan dolayı bu mecrada sanatçıyla anlık etkileşim mümkün olmamaktadır.

Sosyal medya mecraları, sanatçılar ile sanatseverler arasında anlık etkileşim sağlanabilen yerlerdir. Facebook, Instagram ve Twitter gibi sosyal medya mecralarında kişi oluşturmak istediği gönderi üzerinden görüntülenme, beğenme ve beğenilmeme sayısını görebildiği gibi anlık eleştiriler de alabilmektedir. Özellikle Instagram sadece fotoğraf ve video paylaşımının yapıldığı bir mecra olarak bilindiği için bugün en çok sanat eserinin paylaşıldığg yerdir.

Hat sanatının teșhirinin yıllar içerisindeki bu değișimini, bir yönüyle en eski sergileme usullerine ilave olarak gelișen yeni yöntemler bağlamında değerlendirebiliriz. Bugün hattatlar cami yazıları yazdığı gibi yazdıkları levhaları sosyal medya üzerinden teşhir etmektedirler. Sosyal medya mecralarının doğası gereği bir hız söz konusudur. Hızlı bir şekilde tüketilen bu içeriklerin tesirinin ne derece olduğu ise yeterince net değildir.

Sanatçların kişisel internet sayfaları ve sosyal medya mecralarına ilave olarak müzelerin internet sayfaları ve sanat üzerine kurulan özel internet siteleri mevcut koleksiyonların birlikte görülebileceği yerlerdir. Yurt dıșındaki müze ve kütüphanelerde bulunan hat eserlerinin yüksek çözünürlüklü taramalarına kolaylıkla ulaşılmaktadır. Bunlar arasında Universtiy of Michigan Library, Metropolitan Museum of Art ve British Museum gibi birçok uluslararası kütüphane ve müze internet ortamında sınırlı sayıda koleksiyonlarında bulunan eserleri erişime açmıştır.

Eski sanatkârların kısa özgeçmişlerinin ve eserlerinin topluca görülmesine hizmet amacıyla ülkemizde internet siteleri kurulmuştur. 2008 yllında kurulan kalemguzeli.org ${ }^{25}$ bu amaca hizmet etmektedir. Eski üstatların ve günümüz hattatlarının kısa özgeçmişlerinin ve eserlerinin yer aldığı internet sitesi, aynı zamanda hat sanatı hakkında etkinliklerin duyurulduğu bir mecradır. $\mathrm{Bu}$ alandaki bir diğer site ise kalemguzeli.org internet sitesinin bir örneği olarak 2017'de Albayrak Holding tarafından oluşturulan ketebe.org sitesidir. ${ }^{26}$ Sitenin yayın kurulunu oluşturan Mustafa Parıldar, Sami Naddah, Abdurrahman Depeler ve Seyit Ahmet Depeler uluslararası başarılara sahip günümüzün kıymetli hattatlarındandır. (Resim 10 ).

Aralık 2019'da Çin'in Wuhan şehrinden çıkan ve kısa sürede tüm dünyayı etkisi altına alan Covid19 virüsü sosyal hayatı birçok yönden olumsuz etkilemiştir; bunlardan biri de sanat camiasıdır. Müze, sanat galerisi ve sergi

Kalem Güzeli “Site Hakkında” (Erişim 1 Haziran 2021.)

26 Ketebe "Künye" (Erişim 1 Haziran 2021.) 
salonlarının kapatılmasıyla birlikte sanat sergileri internet ortamında gerçekleşmeye başlamıştır. Başlangıçta kişisel internet sayfaları, kurum sayfaları ve Instagram hesapları aracılığıyla yapılan bu sergiler, șimdilerde sadece bir sanat sergisinin düzenlenmesi üzerine kurulan internet siteleri üzerinden yapılmaktadır. Artsteps.com ve kunstmatrix.com gibi sitelerle ücretli veya ücretsiz oluşturulan bu sanal sergi salonlarında bir nevi yürüyormuşçasına eserleri inceleme imkânı bulunmaktadır.

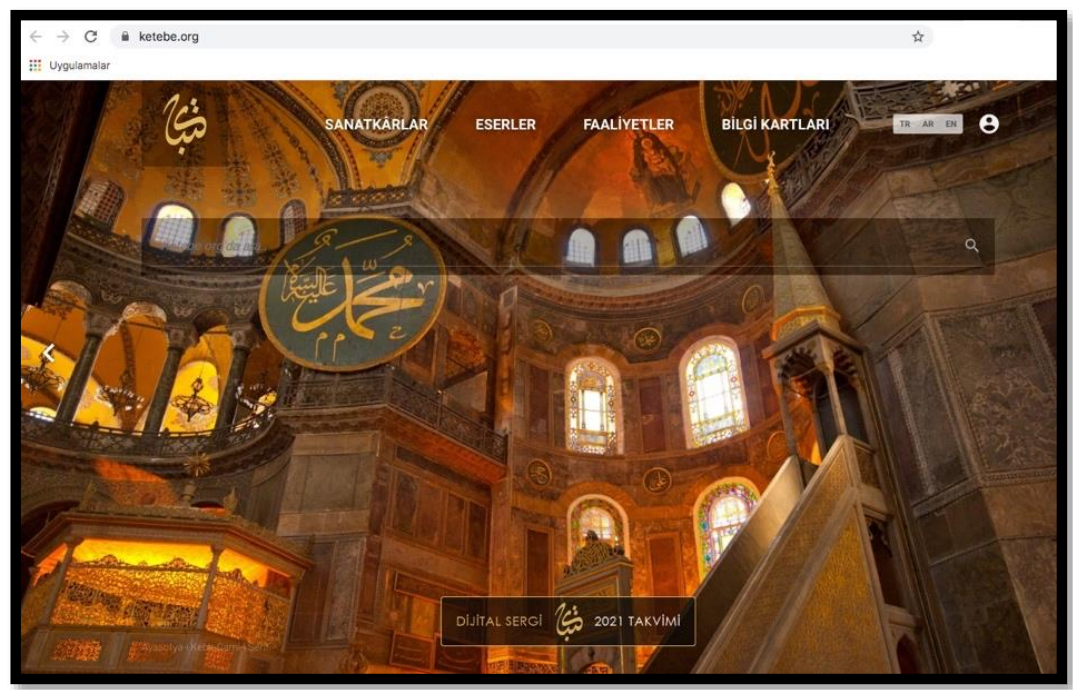

Resim 8 Ketebe.org Internet Sitesi Ana Sayfası (https://www.ketebe.org/),

Erișim 26 Haziran 2021

Artırılmış sanal gerçeklik (AR) teknolojileri her geçen gün yaygınlaşarak birçok alanda kullanılmaya başlamıştır. Bu teknolojiyle sanat sergileri tertip edilmeye başlanmıştır. Artırılmış sanal gerçeklik gözlüklerinin yaygınlaşmasıyla birlikte bu şekilde düzenlenecek sergilerin sayısının artacağı ortadadır. Bu durum eserlerin mekândan ve zamandan bağımsız olarak sergilenmesine yol açacak ve sergi anlayışını çok daha farklı bir boyuta taşıyacaktır.

Günümüzde video oyun konsolları için üretilen hareket kontrol sistemi ve VR gözlüklerle dijital sanat yapabilme imkânı sunan yazılımlar geliştirilmektedir. Google tarafından geliştirilen "tiltbrush" adlı program buna iyi bir örnektir. Klasik hat sanatı eğitimini İstanbul'da Efdaluddin Kılıç'tan almış olan Pakistan asıllı İngiliz hattat Soraya Syed'ın denemeleri bu konuda bir başlangıç olarak değerlendirilmelidir. ${ }^{27}$ (Resim 11 ) $\mathrm{Bu}$ ve benzeri yeni teknolojilerin hat sanatını nasıl etkileyeceğini zaman gösterecektir.

27 Youtube “Soraya's Story - A Calligrapher's Journey” (Erişim: 10 Temmuz 2021) 


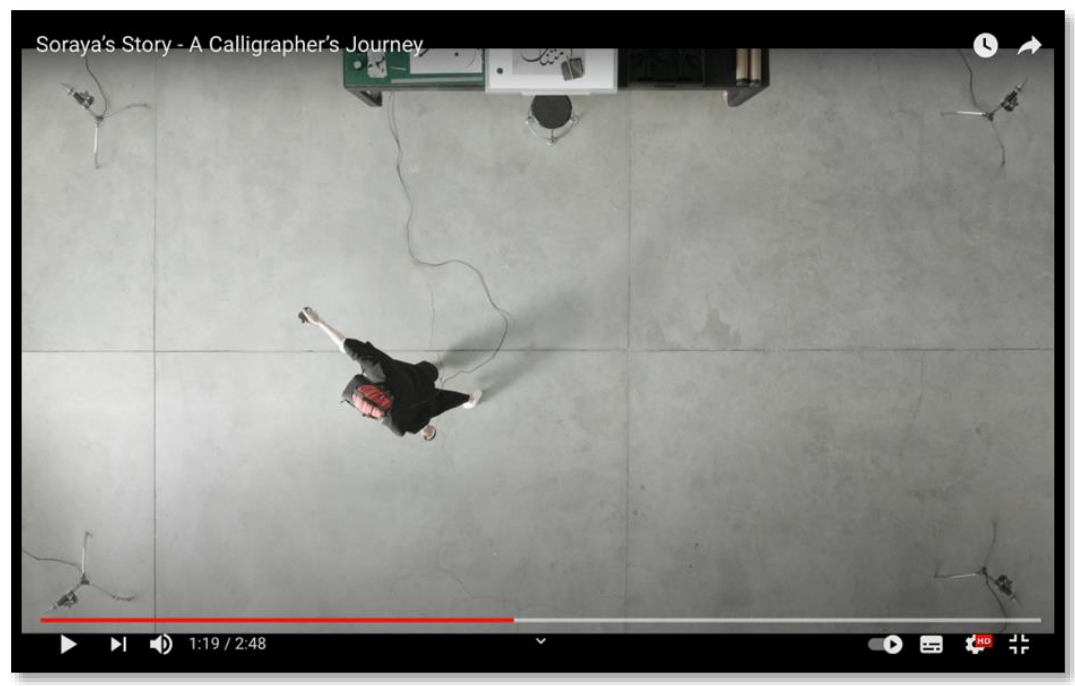

Resim 9 Soraya's Story - A Calligrapher's Journey (https://www.youtube.com/watch?v=vDCuRG4rQOE),

Erişim 10 Temmuz 2021

\section{Sonuç}

Araştırmamızda hat sanatının kısa tarihi, asırlar boyunca teşhir usullerinin geçirdiği değişimle beraber kronolojik sıraya uygun olarak sunulmuş ve günümüzde dijital mecradaki son gelişmelerle birlikte değișen teşhir metotları ele alınmıştır.

Araştırmamız neticesinde ulaştığımız sonuçlar şu şekildedir:

1. İnternet siteleri, sosyal medya ve sanal sergi oluşturulan internet sitelerinde eserlerin sergilenmesi çok yeni bir alan olduğu için bu konuda yeterli literatür oluşmamıştır.

2. Sanatseverler sosyal medya gibi hızlı bir akış düzleminde sanat eserlerine yeterince dikkat kesilemeden görseller arasında kaybolmaktadır. Bu bir anlamda sosyal medyanın yapılış amacıdır. Hal böyle olunca eserlerin detaylı incelenmesine imkân oluşmamaktadır. Bununla beraber müzeler ve ketebe.org gibi hat sanatı için müstakil kurulan internet sitelerinde eserlerin yüksek çözünürlüklü dijital taramaları bulunduğu için en ince detaylarına kadar eserler incelenebilmektedir.

3. Hat sanatında tüm detaylar çok önemlidir. Bu detayların ekran üzerinden yeterince algılanamayacağı söz konusudur.

4. Hat sanatını tezhip, cilt, çini, kalem işi, ahşap ve taş işçiliği gibi diğer İslam sanatlarıyla bir bütün olarak değerlendirme imkanı dijital mecralarda ortadan kalkmış durumdadır.

5. İnternet ortamının hız endişesi sanat eserlerinin yapılış amaçlarından biri olan kalıcı olma fikriyle ters düşmektedir. 
6. İnternet mecrasında sergilenen tüm eserler, farklı grafik programlarıyla üzerinde değişim yapılabildiği için eserlerin aslını yansıtmamaktadır. Bu mecranın teşhir ortamını eserin sadece bir tanıtımı olarak değerlendirmek daha doğru bir bakış açısı olacaktır.

7. Sosyal medya aracilığıyla paylaşılan eserler, sanatçı ve sanatsever arasındaki bağı kuvvetlendirmesi açısından olumlu bir sonuç ortaya koymaktadır.

8. Eserlerini dijital mecrada sergileyen sanatçıların eserleri üzerinden tenkitler alması, eserlerin estetik ve hat sanatına mahsus durumlarının konuşulması aday sanatkârların sanatlarını geliştirebilmesi aşısından müspet bir neticedir.

9. Hat sanatında eski üstatların ve günümüz hattatlarının yazılarını incelemenin bir hat talebesi için önemine binaen, bu yazllara ulaşımın kolay olması hat sanatında yeni ve nitelikli eserlerini çıkmasına ortam sağlayacaktır.

10. İçinde bulunduğumuz salgın hastalık sebebiyle yüz yüze eğitimlere ara verilmiștir. Hat sanatı eğitiminin üniversiteler ve hattatlar tarafından dijital mecrada kesintisiz olarak devam ettirildiği bilinmektedir. Eski devirlerdeki mektup ile meşke devam etme bugünlerde dijital mecralardan yaşatılmaktadır.

Finansman / Funding:

This research received no external funding. / Bu araștırma herhangi bir dıș fon almamıștır.

Çıkar Çatışması / Conflicts of Interest:

The author declare no conflict of interest. / Yazar, herhangi bir çıkar çatışması olmadığını beyan eder. 


\section{Kaynakça}

Alparslan, Ali. Osmanlı Hat Sanatı Tarihi. İstanbul: YKY Yayınları, 3.Basım, 2007.

Altunay, Hakan Can. Türkiye Örneğinde İnternet Ăg Altyapısının Tıkanıklık Analizi, Sakarya Üniversitesi, Fen Bilimler Enstitüsü, Yüksek Lisans Tezi, 2014.

Ayverdi, Ekrem Hakkı. Fâtih Devri Hattatları ve Hat Sanatı. İstanbul: İstanbul Fethi Derneği Yayınları, 1. Basım, 1953.

Derman, Uğur. “Hilye”. Türkiye Diyanet Vakfı İslâm Ansiklopedisi. 18/47-51. İstanbul: TDV Yayınları, 1998.

Çetin, Nihad M. "Aklam-ı Sitte". Türkiye Diyanet Vakfı İslâm Ansiklopedisi. 2/276-280. İstanbul: TDV Yayınları, 1989.

Serin, Muhittin. "Iİn'ül Bevvab". Türkiye Diyanet Vakfı İslâm Ansiklopedisi. 20/534-535. İstanbul: TDV Yayınları, 1999.

Serin, Muhittin. "Yâkût el-Müsta'sımî". Türkiye Diyanet Vakfı İslâm Ansiklopedisi. 43/291-293. İstanbul: TDV Yayınları, 2013.

Uğur Derman, "Hasan Çelebi". Türkiye Diyanet Vakfı İslâm Ansiklopedisi. 16/312-313. İstanbul: TDV Yayınları, 1997.

Gedik, Ahmet. “Karatay Medresesi Taçkapısı'ndaki Celî Yazıların Hat San’atı Bakımından Değerlendirilmesi”. İstem 3 (2004), 165-189.

Nefeszâde İbrâhim (Neșre Hazırlayan Kilis Muallim Rifat). Gülzâr-ı Savâb. İstanbul: Güzel Sanatlar Akademisi Neşriyat, 1.Basım, 1939.

Reisoğlu, Cansu. Ahlat Meydan Mezarlığı'ndaki Hacı Miran Bin Yusuf'a Ait Mezar Taşları. Yüzüncü Yıl Üniversitesi, Sosyal Bilimler Enstitüsü, Yüksek Lisans Tezi, 2016.

Yazır, Mahmud Bedreddin. Medeniyet Âleminde Yazı ve İslâm Medeniyetinde Kalem Güzeli, Ankara.:Diyanet Isşleri Başkanlığı Yayınları, 1. Basım, 1981.

Serin, Muhittin. Hat Sanatı ve Meşhur Hattatlar. İstanbul: Kubbealtı Neşriyat, 3. Basım, 2008.

We Are Social, We Are Social Ltd,"Digital In 2020". Erişim 15 Haziran 2021. https://wearesocial.com/digital-2020

Kalem Güzeli, Kalem Güzeli, "site hakkında”. Erișim 1 Haziran 2021. http://www.kalemguzeli.org/index.php?go=hakkında

Ketebe, Ketebe, "künye”. Erişim 1 Haziran 2021. https://www.ketebe.org/kunye

Youtube "Soraya's Story - A Calligrapher's Journey" (Erişim 10 Temmuz 2021) https://www.youtube.com/watch?v=vDCuRG4rQ0E 